\title{
Peramalan Tingkat Profitabilitas Bank Syariah dengan Menggunakan Model Fungsi Transfer Single Input
}

\author{
Adina Astasia $^{1, \text { a) }}$, Septie Wulandary ${ }^{2, b)}$, Ahid Nur Istinah ${ }^{3, c)}$, Istiqomatul Fajriyah Yuliati ${ }^{4, d)}$

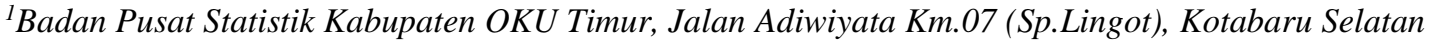 \\ ${ }^{2}$ Badan Pusat Statistik Provinsi Jambi, Jalan A. Yani No. 4, Telanaipura, Jambi \\ ${ }^{3}$ Badan Pusat Statistik Kota Bandung, Jl. Jenderal Gatot Subroto No.93, Kota Bandung, Jawa Barat \\ ${ }^{4}$ Badan Kependudukan dan Keluarga Berencana Nasional, Jl. Permata No. 1, Jakarta Timur \\ Email: ${ }^{\text {a) }}$ adinaastasia@bps.go.id, ${ }^{\text {b) }}$ septie@bps.go.id, ${ }^{\text {c) }}$ ahid@bps.go.id, ${ }^{\text {d) }}$ istiqomatul.fy@bkkbn.go.id
}

\begin{abstract}
The transfer function is a combination of the Autoregressive Integrated Moving Average (ARIMA) model and multiple regression analysis. This is a forecasting technique to get the future predictive value of a periodic output series based on the past values of the series itself and its influence spreads from the input variable to the output variable. In this study, the single input transfer function model is used to analyze the prediction of the development of Islamic Bank Return on Assets (ROA) and see the influence of conventional commercial bank interest rate factors in influencing Islamic Bank ROA in Indonesia. The data source used was obtained from Bank Indonesia with a monthly series from October 2014 to December 2018. The results of the analysis showed that conventional commercial bank savings rates significantly influence ROA in the third lag. Based on the results of forecasting shows that the single input transfer function model is quite good in predicting Islamic Bank Return on Assets (ROA).
\end{abstract}

Keywords: Transfer Function, Single Input, Islamic Bank ROA, conventional bank interest rates

\begin{abstract}
Abstrak
Fungsi transfer adalah gabungan dari model Autoregressive Integrated Moving Average (ARIMA) dan analisis regresi berganda. Teknik ini merupakan suatu teknik peramalan guna mendapatkan nilai prediksi masa depan dari suatu deret berkala output yang didasarkan pada nilai-nilai masa lalu dari deret itu sendiri dan pengaruhnya menyebar dari variabel input ke variabel output. Dalam penelitian ini, model fungsi transfer single input digunakan untuk menganalisis prediksi perkembangan Return on Assets (ROA) bank syariah dan melihat pengaruh faktor suku bunga tabungan bank umum konvensional dalam mempengaruhi ROA bank syariah di Indonesia. Sumber data yang digunakan diperoleh dari Bank Indonesia dengan series bulanan dari bulan Oktober 2014 sampai dengan bulan Desember 2018. Hasil analisis menunjukkan bahwa suku bunga tabungan bank umum konvensional berpengaruh secara signifikan terhadap ROA pada lag ketiga. Berdasarkan hasil peramalan menunjukkan bahwa model fungsi transfer single input cukup baik dalam memprediksi ROA bank syariah.
\end{abstract}

Kata-kata kunci: Fungsi Transfer, Single Input, ROA Bank Syariah, Suku Bunga Bank Konvensional 


\section{PENDAHULUAN}

Bank berdasarkan prinsip syariah atau bank syariah di Indonesia muncul sejak tahun 1991. Kemunculan bank-bank yang berlandaskan syariat Islam tersebut diharapkan mampu mendukung perkembangan perekonomian negara. Tujuan dari diadopsinya sistem ekonomi Islam ke dalam industri perbankan nasional adalah untuk memperbaiki kinerja industri perbankan secara menyeluruh. Salah satu indikator untuk menilai kinerja keuangan bank adalah dengan melihat tingkat profitabilitasnya serta tingkat efisiensinya. Ukuran profitabilitas yang digunakan adalah Return on Asset (ROA). ROA memfokuskan pada kemampuan perusahaan untuk memperoleh earning dalam operasi perusahaan. Semakin besar ROA menunjukkan kinerja keuangan yang semakin baik, karena tingkat kembalian (return) semakin besar (Husnan, 1992). ROA digunakan untuk mengukur efisiensi dan efektifitas perusahaan dalam menghasilkan keuntungan dengan memanfaatkan aktiva yang dimilikinya. ROA merupakan rasio antara laba sebelum pajak terhadap total aset. Dalam ROA, akan terlihat kemampuan bank dalam menghasilkan laba bersih dengan membandingkan total aset yang dimiliki. Sehingga apabila semakin besar ROA suatu bank, maka tingkat keuntungan yang didapat oleh bank juga semakin besar. Dari data yang ada menunjukkan bahwa ROA pada perbankan syariah di Indonesia selama Oktober 2014 - Desember 2018 berfluktuasi, dengan rata-rata sebesar 0,83\%. Rata-rata pergerakan ROA pada bank syariah tersebut masih di bawah nilai ROA yang ideal yaitu sebesar 1,5\%. Hal tersebut memperlihatkan bahwa industri perbankan syariah di Indonesia belum ideal.

Kinerja perbankan syariah, dalam hal ini ROA, tidak terlepas dari kondisi lingkungan industri perbankan, terutama persaingan antara bank syariah dan bank konvensional. Penelitian sebelumnya menyatakan bahwa konsumen jasa perbankan merupakan konsumen rasional, dimana mereka akan memilih bank yang memberikan keuntungan lebih besar. Oleh karena itu, kebijakan yang dilakukan oleh bank konvensional akan mempengaruhi ROA bank syariah. Dalam penelitian ini, kebijakan bank konvensional digambarkan dengan tingkat suku bunga tabungan bank konvensional. Hubungan antara suku bunga tabungan bank umum konvensional dan ROA bank syariah akan menjadi sesuatu yang menarik jika bisa dikaji dan diteliti lebih dalam, mengingat masih sedikitnya penelitian mengenai hubungan kedua variabel tersebut di Indonesia.

Untuk kepentingan analisis dan prediksi, digunakan salah satu model multivariate time series, yaitu model fungsi transfer single input pada data kinerja perbankan dari Bank Indonesia. Model fungsi transfer single input dapat digunakan untuk menganalisis prediksi perkembangan ROA bank syariah dan melihat pengaruh faktor suku bunga tabungan bank umum konvensional dalam mempengaruhi ROA bank syariah di Indonesia.

Menurut Makridakis (1999), fungsi transfer menggabungkan beberapa karakteristik dari model ARIMA dan analisis regresi berganda. Tujuan pemodelan fungsi transfer adalah untuk menetapkan model sederhana, yang menggabungkan deret berkala output dengan deret input dan seluruh pengaruh lain yang disebut dengan deret gangguan (noise). Jadi, model fungsi transfer ini dapat digunakan untuk mendapatkan hasil peramalan berdasarkan beberapa variabel bebas secara simultan.

Beberapa penelitian yang menggunakan fungsi transfer antara lain Wahyuningsih (2012) yang memodelkan Nilai Tukar Petani (NTP) dengan pendekatan fungsi transfer dan multivariate adaptive regression spline time series. Aryasita dan Mukarromah (2013) menganalisis fungsi transfer pada harga cabai merah yang dipengaruhi oleh curah hujan di Surabaya. Pada penelitian ini, digunakan fungsi transfer single input untuk meramalkan ROA bank syariah, dengan variabel input suku bunga tabungan bank umum konvensional.

\section{METODE PENELITIAN}

\section{Sumber Data dan Variabel Penelitian}

Sumber data yang digunakan diperoleh dari Bank Indonesia. Pada analisis ini, variabel yang digunakan adalah variabel Return on Assets (ROA) bank syariah dan variabel tingkat suku bunga tabungan bank umum di Indonesia dengan series bulanan dari bulan Oktober 2014 sampai dengan 
bulan Desember 2018. Pengolahan data dilakukan menggunakan program R versi 3.5.1 dan program SAS.

\section{Fungsi Transfer Single Input}

Fungsi transfer adalah gabungan dari model ARIMA dan analisis regresi berganda. Metode ini merupakan teknik peramalan guna mendapatkan nilai prediksi masa depan dari suatu deret berkala output $\left(Y_{t}\right)$ didasarkan pada nilai-nilai masa lalu dari deret itu sendiri dan pengaruhnya menyebar dari variabel input $\left(X_{t}\right)$ ke variabel output. Oleh karena itu, model fungsi transfer merupakan teknik peramalan yang dinamis. Dalam penelitian ini, ROA bank syariah merupakan deret output sementara tingkat suku bunga tabungan bank konvensional sebagai deret input.

Model fungsi transfer single input menurut Makridakis (1999) yaitu:

$$
Y_{t}=v(B) X_{t}+n_{t}
$$

dengan:

$Y_{t} \quad=$ deret output

$X_{t}=$ deret input

$n_{t} \quad=$ pengaruh kombinasi dari seluruh faktor yang mempengaruhi $Y_{t}$ atau disebut juga deret noise $v(B)=\left(v_{0}+v_{1} B+v_{2} B^{2}+\cdots+v_{k} B^{k}\right)$ dan $k$ adalah orde fungsi transfer

Orde dari fungsi transfer $k$ menjadi orde tertinggi untuk proses pembedaan dan terkadang nilainya dapat lebih besar sehingga model fungsi transfer juga dapat ditulis sebagai berikut:

$$
v(B)=\frac{\omega(B)}{\delta(B)}
$$

dan

$$
n_{t}=\frac{\theta(B)}{\phi(B)} a_{t}
$$

sehingga

$$
y_{t}=\frac{\omega(B)}{\delta(B)} x_{t-b}+\frac{\theta(B)}{\phi(B)} a_{t}
$$

dengan:

$y_{t}=$ nilai $Y_{t}$ yang telah stasioner

$x_{t} \quad=$ nilai $X_{t}$ yang telah stasioner

$n_{t} \quad=$ deret noise

$a_{t} \quad=$ nilai noise acak

$\omega(B)=\omega_{0}+\omega_{1} B+\omega_{2} B^{2}+\cdots+\omega_{s} B^{s}$

$\delta(B)=\delta_{0}+\delta_{1} B+\delta_{2} B^{2}+\cdots+\delta_{r} B^{r}$

$\theta(B)=\theta_{0}+\theta_{1} B+\theta_{2} B^{2}+\cdots+\theta_{r} B^{r}$

$\phi(B)=\phi_{0}+\phi_{1} B+\phi_{2} B^{2}+\cdots+\phi_{p} B^{p}$

$\omega_{j}(B)=$ operator moving average order $s_{j}$ untuk variabel ke-j

$\delta_{j}(B)=$ operator autoregressive order $r_{j}$ untuk variabel ke $\mathrm{j}$

$\theta(B)=$ operator moving average order $q$

$\phi(B)=$ operator autoregressive orde $p$

Tahapan Pemodelan Fungsi Transfer Single Input

Tahapan yang dilakukan dalam pemodelan menggunakan Fungsi Transfer Single Input yaitu identifikasi, penaksiran parameter, uji diagnosa fungsi transfer, dan peramalan. Lebih lanjut tahapan tersebut diuraikan sebagai berikut. 


\section{Persiapan Deret Input dan Output}

Persiapan deret input dan output dilakukan untuk memperoleh data yang stasioner, baik dalam ratarata maupun ragam. Data deret waktu dikatakan stasioner jika perilaku data tersebut berfluktuasi di sekitar nilai tengah dan ragam yang relatif konstan untuk seluruh periode waktu.

Dalam penelitian ini digunakan uji Augmented Dickey Fuller (ADF) untuk menguji kestasioneran dalam rata-rata. Jika hasil uji ADF diperoleh $p$-value lebih kecil dari taraf nyata $(\alpha=0,05)$ maka dapat disimpulkan bahwa data stasioner, begitupun sebaliknya. Jika data belum stasioner terhadap rata-rata, maka akan dilakukan differencing (pembedaan).

Data juga harus memenuhi syarat stasioner dalam ragam. Jika Plot Box-Cox menunjukkan nilai batas bawah dan batas atas lambda $(\lambda)$ melalui nilai 1 (satu), maka dapat dikatakan bahwa data deret waktu tersebut sudah stasioner dalam ragam. Apabila data belum stasioner terhadap ragam, maka dilakukan transformasi Box-Cox.

\section{Identifikasi Deret Input dan Output dengan ARIMA}

Model ARIMA (Autoregressive Integrated Moving Average) digunakan untuk melakukan penaksiran awal deret input. Identifikasi awal model ARIMA dilakukan dengan menggunakan plot ACF (Autocorrelation Function) dan PACF (Partial Autocorrelation Function). Setelah ditentukan model ARIMA yang digunakan, maka dilakukan estimasi parameter dan pemeriksaan diagnostik model.

Pemeriksaan diagnostik dapat dibagi ke dalam dua bagian yaitu uji signifikasi parameter dan uji asumsi white noise. Uji signifikasi parameter dapat dilihat dari nilai t-hitung dari penduga parameter tersebut, jika nilai t-hitung dari penduga parameter lebih besar daripada nilai t-tabel atau nilai peluang statistik t lebih kecil dari taraf nyata $(\alpha=0,05)$, maka penduga parameter dikatakan signifikan (berpengaruh) dan sebaliknya.

\section{Pemutihan Deret Input dan Output}

Proses pemutihan adalah proses menghilangkan seluruh pola yang diketahui agar mendapatkan deret yang white noise. Pemutihan dilakukan untuk menghilangkan autokorelasi sebelum menghitung korelasi silang. Deret input $\left(x_{t}\right)$ menjadi $a_{t}$ dan deret output $\left(y_{t}\right)$ menjadi $\left(\beta_{t}\right)$ setelah diputihkan sebagai berikut:

$$
\begin{aligned}
& a_{t}=\frac{\phi_{x}(B)}{\theta_{x}(B)} x_{t} \\
& \beta_{t}=\frac{\phi_{x}(B)}{\theta_{x}(B)} y_{t}
\end{aligned}
$$

dengan $\phi_{\alpha}(B)$ adalah operator autoregressive, $\theta_{\alpha}(B)$ adalah operator moving average, dan $a_{t}$ adalah white noise.

\section{Penghitungan Korelasi Silang dan Penentuan Nilai $(b, r, s)$}

Deret input dan deret output yang digunakan dalam perhitungan korelasi silang dan autokorelasi adalah yang telah diputihkan. Korelasi silang digunakan untuk menentukan kekuatan serta arah hubungan antara $a_{t}$ dan $\beta_{t}$. Selain itu digunakan untuk meyakinkan apakah benar terjadinya intervensi tersebut langsung berpengaruh terhadap data respon (Wei, 2006). Jika nilai korelasi silang pada lag positif ke $k$, maka pengaruh variabel input akan kelihatan setelah lag ke- $k$.

Pada model fungsi transfer single input, perhitungan korelasi silang digunakan untuk mengetahui nilai $r, s$, dan $b$ yang diidentifikasikan dari plot korelasi silang (CCF). Setelah didapatkan nilai $r, s$, dan $b$ pada masing-masing input, dilakukan korelasi silang secara serentak antara nilai output terhadap 
seluruh variabel input. Berikut merupakan aturan yang digunakan untuk menduga $r, s$, dan $b$ dari suatu fungsi transfer (Wei, 2006):

1. Nilai $b$ menyatakan bahwa $y_{t}$ tidak dipengaruhi oleh $x_{t}$ sampai periode $t+b$. Besarnya $b$ dapat ditentukan dari lag yang pertama kali signifikan pada plot korelasi silang.

2. Nilai $s$ menyatakan berapa lama deret output $y_{t}$ secara terus menurus dipengaruhi oleh $x_{t-b-1}, x_{t-b-2}, \cdots, x_{t-b-s}$. Nilai $s$ adalah bilangan pada lag plot korelasi silang sebelum terjadinya pola menurun.

3. Nilai $r$ menyatakan bahwa $y_{t}$ dipengaruhi oleh nilai-nilai masa lalu dari $y_{t}$ yaitu $y_{t-1}, y_{t-2}, \ldots y_{t-r}$. Terdapat tiga kondisi pada nilai $r$ yang mempunyai indikasi pemodelan berbeda, yaitu:

$r=0$, apabila ada beberapa lag plot pada korelasi silang yang terpotong.

$r=1$, apabila plot pada korelasi silang menunjukkan suatu pola eksponensial menurun $r=2$, apabila plot pada korelasi silang menunjukkan suatu pola eksponensial menurun dan mengikuti pola sinus.

\section{Estimasi Parameter Model Fungsi Transfer}

Model fungsi transfer single input adalah sebagai berikut :

$$
y_{t}=\frac{\omega(B)}{\delta(B)} x_{t-b}+\frac{\theta(B)}{\phi(B)} a_{t}
$$

Untuk mencari taksiran awal terbaik digunakan Conditional Maximum Likelihood. Diasumsikan bahwa $a_{t}$ adalah deret white noise berdistribusi $N\left(0, \sigma_{a}^{2}\right)$ dan berikut adalah fungsi likelihoodnya :

$$
L\left(\delta, \omega, \phi, \sigma^{2}{ }_{a} \mid b, x, y, x_{0}, y_{0}, a_{0}=\left(2 \pi \sigma^{2}{ }_{a}\right)^{n / 2} \exp \left[-\frac{1}{2 \sigma_{a}^{2}} \sum_{t=1}^{n} a_{t}^{2}\right]\right.
$$

Menurut Wei (2006), estimasi parameter model fungsi transfer dapat juga menggunakan Conditional Least Squares dan mengasumsikan $a_{t}$ yang tidak diketahui sama dengan nol.

Setelah diperoleh model fungsi transfer single input, dapat dilanjutkan dengan peramalan.

\section{Pemeriksaan Diagnostik}

Pemeriksaan diagnostik dilakukan untuk melihat kebaikan model fungsi transfer yang telah dibentuk. Pemeriksaan diagnostik dibagi menjadi pengujian asumsi residual white noise dan uji asumsi kenormalan.

Asumsi white noise artinya residual antar lag tidak ada korelasi. Pengujian asumsi ini dapat dilakukan melalui uji Ljung Box (Wei, 2006).

Hipotesis $\quad: H_{0}: \rho_{1}=\rho_{2}=\cdots=\rho_{k}=0$ (residual white noise)

$H_{1}$ : minimal ada $\rho_{k} \neq 0$ (residual tidak white noise)

Statistik uji :

$$
Q=n(n+2) \sum_{k=1}^{K}(n-k)^{-1} \hat{\rho}_{k}^{2}
$$

keterangan:

$\hat{\rho}_{k}^{2}=$ autokorelasi residual pada lag ke-k

$n=$ banyaknya residual

$K=$ lag maksimum

Uji kenormalan dilakukan untuk mengetahui apakah residual mengikuti distribusi normal atau tidak. Uji Normal Probability Plot atau uji P-P Plot menjadi salah satu alternatif yang cukup efektif untuk pengujian asumsi kenormalan pada residual. Pendeteksian asumsi kenormalan dari residual ini dilakukan dengan melihat titik-titik plot apakah berada disekitar garis diagonal atau tidak. 


\section{HASIL DAN PEMBAHASAN}

Plot data time series dari tingkat suku bunga tabungan bank umum (SB) dan Return on Asset (ROA) bulan Oktober 2014 sampai dengan bulan Desember 2018 ditunjukkan pada Gambar 1.

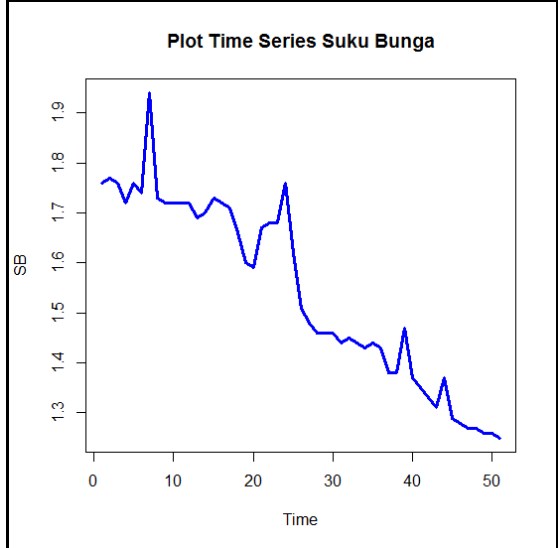

(a)

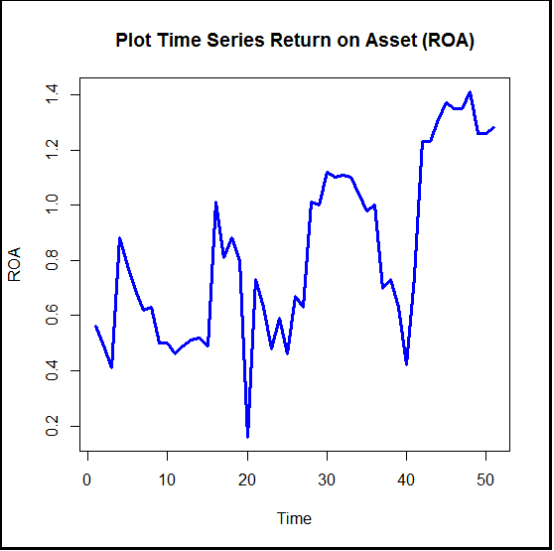

(b)

GAMBAR 1. Plot time series dari (a) SB dan (b) ROA

\section{Mempersiapkan Deret Input dan Output (Penstasioneran Data)}

Langkah pertama dari prosedur ARIMA Box-Jenkins adalah mengidentifikasi data untuk menentukan kestasioneran.

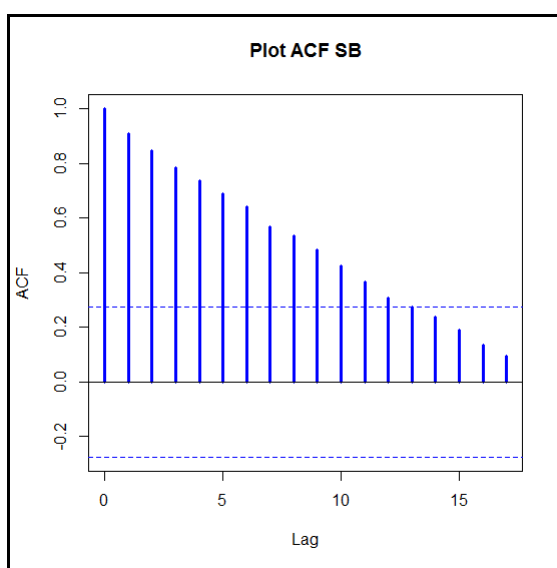

(a)

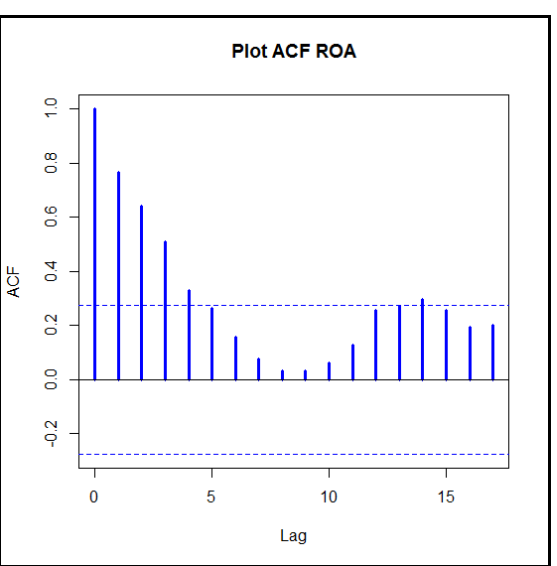

(b)

GAMBAR 2. Plot autokorelasi (ACF) dari (a) SB dan (b) ROA

Bentuk plot time series pada Gambar 1 dan plot autokorelasi pada Gambar 2 dari SB dan ROA menunjukkan bahwa kedua variabel tersebut belum stasioner dalam rataan. Sehingga kedua set data tersebut perlu dilakukan differencing satu kali sehingga menghasilkan plot time series seperti yang ditunjukkan pada Gambar 3. 


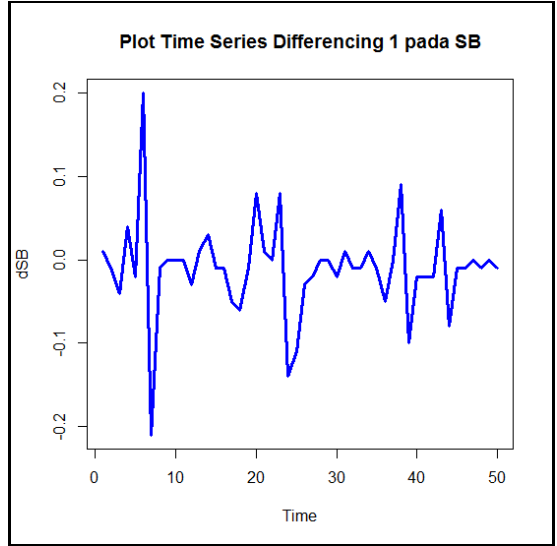

(a)

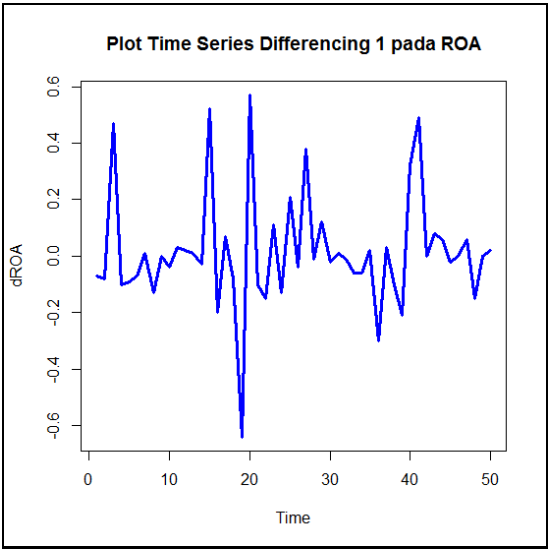

(b)

GAMBAR 3. Plot time series setelah dilakukan differencing satu kali pada (a) SB dan (b) ROA

Pembedaan (differencing) satu kali telah menghasilkan deret output dan input yang telah stasioner (Gambar 3). Kestasioneran juga diuji dengan menggunakan Augmented Dicky-Fuller (ADF). Hasil uji menunjukkan bahwa kedua variabel telah stasioner, hal ini terlihat dari nilai $p$-value variabel SB 0,01 dan ROA 0,012, keduanya lebih kecil dari 0,05 atau tolak $\mathrm{H}_{0}$. Sedangkan untuk melihat stasioneritas dalam ragam dapat dijelaskan dalam bentuk plot Box-Cox. Berdasarkan hasil pengolahan diperoleh nilai batas bawah dan batas atas lambda $(\lambda)$ plot Box-Cox melalui nilai 1 (satu), maka dapat dikatakan bahwa data deret waktu tersebut sudah stasioner dalam ragam.

\section{Identifikasi Deret Input Tingkat Suku Bunga Tabungan Bank Umum}

Langkah-langkah yang dilakukan pada tahap ini yaitu dengan membuat plot ACF dan PACF dari deret input atau variabel SB yang telah dilakukan differencing.

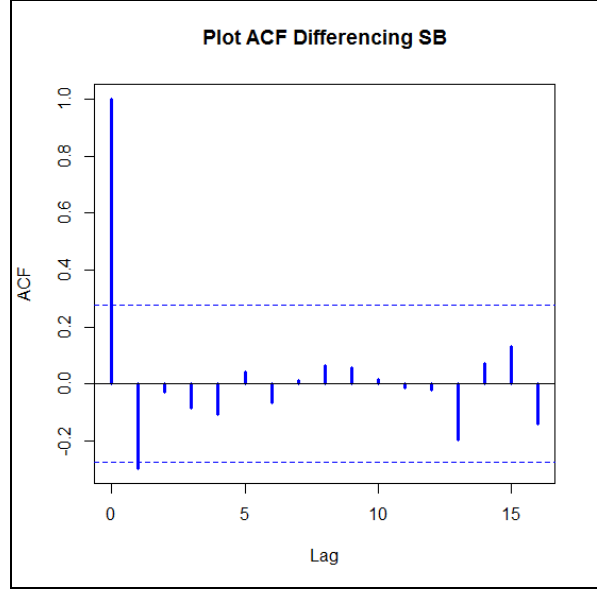

(a)

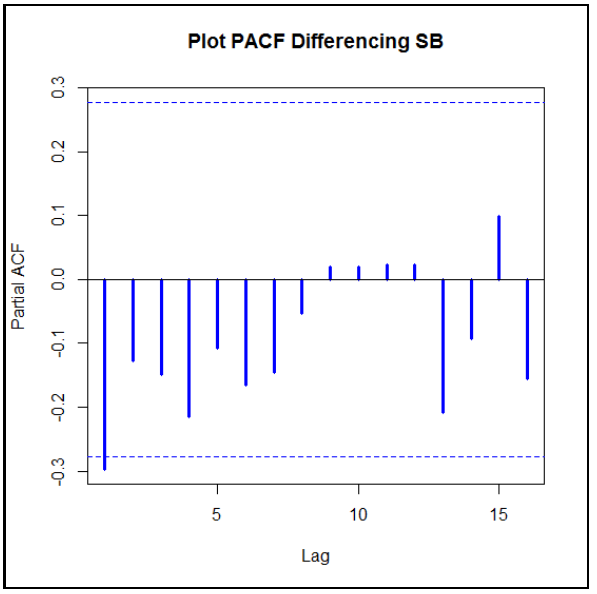

(b)

GAMBAR 4. (a) Plot ACF dan (b) Plot PACF deret input (X) setelah differencing

Gambar 4 menunjukkan nilai plot yang cut off pada ACF dan PACF. Berdasarkan plot ACF dan PACF serta lag-lag yang signifikan pada Gambar 4, maka diduga ada tiga model yang sesuai untuk data SB yaitu ARIMA $(1,1,1), \operatorname{ARIMA}(1,1,0)$, dan $\operatorname{ARIMA}(0,1,1)$.

Berdasarkan Tabel 1, nilai parameter dalam model ARIMA $(1,1,1)$, ARIMA $(1,1,0)$, dan ARIMA $(0,1,1)$ adalah signifikan. Hal tersebut dapat dilihat dari nilai $p$-value yang kurang dari 0,05 . Selanjutnya dipilih model terbaik berdasarkan nilai AIC (Akaike Information Criteria) yang paling kecil, yaitu model ARIMA $(1,1,1)$. 
TABEL 1. Rataan dan simpangan baku dari SB dan ROA

\begin{tabular}{ccccccc}
\hline Model & Parameter & Estimasi & $\begin{array}{c}\text { Standar } \\
\text { Error }\end{array}$ & t-hitung & $\boldsymbol{p}$-value & AIC \\
\hline ARIMA (1,1,1) & $\phi_{1}$ & $-0,2777$ & 0,1358 & $-2,0454^{*}$ & 0,04632 & $-132,48$ \\
\hline \multirow{2}{*}{ ARIMA (1,1,0) } & $\theta_{1}$ & $-1,0000$ & 0,0583 & $-17,1526^{*}$ & $2,586 \mathrm{E}-20$ & \\
\hline ARIMA (0,1,1) & $\phi_{1}$ & $-0,5921$ & 0,1118 & $-5,2961^{*}$ & $4,31 \mathrm{E}-06$ & $-109,54$ \\
\hline
\end{tabular}

Ket: $(*)$ signifikan pada taraf nyata $5 \%,(* *)$ signifikan pada taraf nyata $10 \%$

Uji white noise terhadap masing-masing model dilakukan melalui uji Ljung-Box. Wilayah penolakan hipotesis awal jika statistk uji Ljung-Box lebih besar dari $\chi_{\alpha, k-m}^{2}$ atau bila $p$-value $<\alpha$ dengan alfa 0,05 . Berdasarkan pengolahan diperoleh $p$-value $=0,6886>\alpha(0,05)$ sehingga dapat disimpulkan residual model ARIMA $(1,1,1)$ deret input sudah memenuhi asumsi white noise atau residual antar lag tidak ada korelasi.

\section{Identifikasi Deret Output ROA}

Langkah selanjutnya dalam pemodelan fungsi transfer yaitu melakukan identifikasi model output atau data ROA. Untuk menguji apakah ROA sudah stasioner dilakukan uji akar unit ADF. Berdasarkan uji ADF diperoleh nilai $p$-value dibawah 0.05, yaitu 0.012. Angka tersebut menunjukkan data ROA tidak mengandung unit root atau data sudah stasioner. Dengan demikian model ROA akan dimodelkan sesuai dengan deret inputnya.

\section{Pemutihan Deret Input dan Output}

Berdasarkan hasil identifikasi sebelumnya, model deret input yang diperoleh adalah model ARIMA $(1,1,1)$. Asumsi white noise dan kenormalan dari model ARIMA tersebut sudah terpenuhi. Langkah selanjutnya adalah melakukan pemutihan terhadap deret output. Pemutihan yang dilakukan terhadap deret output mengikuti tranformasi pemutihan deret input. Sehingga dengan mengikuti model ARIMA dari deret inputnya, yaitu ARIMA $(1,1,1)$.

\section{Penghitungan Korelasi Silang dan Penentuan Nilai (b, r, s)}

Penghitungan korelasi silang digunakan untuk menentukan model awal fungsi transfer serta nilai $b$, $r$, dan $s$. Nilai $r$ adalah derajat fungsi $\delta(B), s$ menunjukkan derajat fungsi $\omega(B)$, dan $b$ keterlambatan yang dicatat pada subskrip dari $X_{t-b}$.

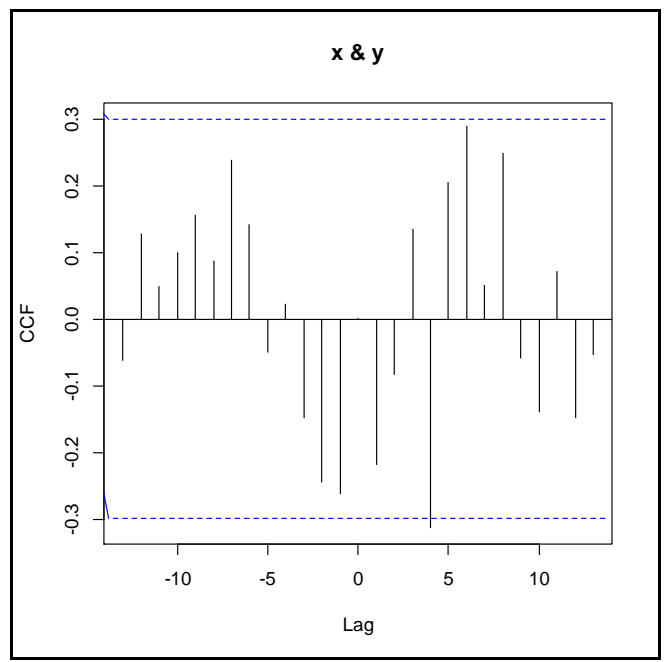

GAMBAR 5. Plot CCF 
Hasil korelasi silang Gambar 5 memperlihatkan terdapat lag signifikan pada lag ke-3 sehingga $b=3$. Plot korelasi silang memiliki pola sinusoidal, sehingga diambil kesimpulan bahwa $r=2$. Berdasarkan hasil korelasi silang tersebut ada beberapa kemungkinan nilai orde dari fungsi transfer. Orde model awal fungsi transfer diduga sebagai berikut $(b=3, r=2, s=3)$ dan $(b=3, r=2, s=4)$.

\section{Estimasi Parameter Model Fungsi Transfer}

Sebelum dilakukan pemodelan fungsi transfer, dilakukan pemodelan ARIMA terhadap deret output yang telah diputihkan. Pemodelan menggunakan fungsi auto arima menghasilkan ARIMA $(0,0,0)$ merupakan model terbaik dari deret output yang telah diputihkan.

TABEL 2. Uji signifikansi parameter model dugaan awal SB terhadap ROA

\begin{tabular}{|c|c|c|c|c|c|}
\hline Orde $(b, r, s)$ & Parameter & Estimasi & Standar Error & t-hitung & p-value \\
\hline$b=3, r=2, s=0$ & $\begin{array}{l}\omega_{0} \\
\delta_{1} \\
\delta_{2}\end{array}$ & $\begin{array}{r}-0,371 \\
-1,5098 \\
-0,9503\end{array}$ & $\begin{array}{r}0,111 \\
0,0336 \\
0,0338\end{array}$ & $\begin{array}{l}-3,34234^{*} \\
-44,9345^{*} \\
-28,1153^{*}\end{array}$ & $\begin{array}{r}0,00178 \\
1,67 \mathrm{E}-36 \\
2,03 \mathrm{E}-28\end{array}$ \\
\hline$b=3, r=2, s=3$ & $\begin{array}{l}\omega_{0} \\
\omega_{1} \\
\omega_{2} \\
\omega_{3} \\
\delta_{1} \\
\delta_{2}\end{array}$ & $\begin{array}{r}-0,00708 \\
0,0541 \\
-0,112 \\
0,35 \\
0,105 \\
-0,924\end{array}$ & $\begin{array}{r}0,52157 \\
0,501 \\
0,551 \\
0,571 \\
0,155 \\
0,169\end{array}$ & $\begin{array}{r}-0,013 \\
0,10798 \\
-0,20326 \\
0,6129 \\
0,67741 \\
-5,46745^{*}\end{array}$ & $\begin{array}{r}0,98923 \\
0,91453 \\
0,83993 \\
0,54328 \\
0,5019 \\
2,46 \mathrm{E}-06\end{array}$ \\
\hline$b=3, r=2, s=4$ & $\begin{array}{l}\omega_{0} \\
\omega_{1} \\
\omega_{2} \\
\omega_{3} \\
\omega_{4} \\
\delta_{1} \\
\delta_{2}\end{array}$ & $\begin{array}{r}0,152 \\
0,196 \\
-0,0834 \\
0,33 \\
0,943 \\
-0,0171 \\
0,492\end{array}$ & $\begin{array}{r}0,551 \\
0,589 \\
0,5964 \\
0,594 \\
0,553 \\
0,421 \\
0,349\end{array}$ & $\begin{array}{r}0,27586 \\
0,33276 \\
-0,13983 \\
0,55555 \\
1,70524^{* *} \\
-0,04061 \\
1,40974\end{array}$ & $\begin{array}{l}0,78403 \\
0,74100 \\
0,88947 \\
0,58153 \\
0,09571 \\
0,96779 \\
0,16615\end{array}$ \\
\hline
\end{tabular}

Ket: $(*)$ signifikan pada taraf nyata $5 \%,(* *)$ signifikan pada taraf nyata $10 \%$

Berdasarkan pada Tabel 2, model dugaan awal yang mempunyai parameter dengan nilai signifikan adalah model dengan orde $b=3, r=2$, dan $s=0$. Hal tersebut bisa ditunjukkan dengan nilai $p$-value parameter-parameternya kurang dari 0,05 . Nilai $b=3$ menunjukkan bahwa SB berpengaruh terhadap ROA pada lag ke-3. Persamaan model dugaan awal fungsi transfer yang terbentuk bisa ditulis sebagai berikut:

$$
y_{t}=\frac{w_{B}}{\delta_{R}} x_{t-b}+\eta_{t}
$$

Dengan $\eta_{t}$ adalah deret noise/gangguan.

\section{Pemeriksaan Diagnostik}

Untuk melihat kebaikan model fungsi transfer yang telah dibentuk, selanjutnya dilakukan uji white noise melalui Uji Ljung-Box. Daerah penolakan hipotesis awal jika statistk uji Ljung-Box lebih besar dari $\chi_{\alpha, k-m}^{2}$ atau bila $p$-value $<\alpha$ dengan alfa 0,05 . Berdasarkan uji tersebut diperoleh $p$-value $=$ $0,4793>\alpha(0,05)$ sehingga disimpulkan residual model fungsi transfer sudah memenuhi asumsi white noise atau residual antar lag tidak ada korelasi. Sehingga model dugaan fungsi transfer dapat digunakan untuk peramalan. 


\section{Uji Kenormalan Residual Arima}

Berdasarkan P-P Plot Gambar 6 menunjukkan bahwa titik-titik dari residual berada di dekat atau mengikuti garis diagonal, maka dapat dikatakan bahwa residual model ARIMA berdistribusi normal.

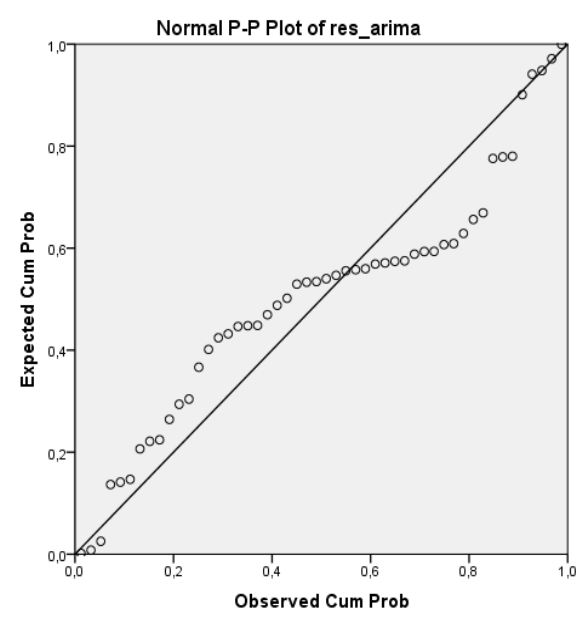

GAMBAR 6. P-P Plot residual

Uji Kenormalan Residual Transfer

Berdasarkan P-P Plot Gambar 7 menunjukkan bahwa titik-titik dari residual berada di dekat atau mengikuti garis diagonal, maka dapat dikatakan bahwa residual model fungsi transfer single input berdistribusi normal.

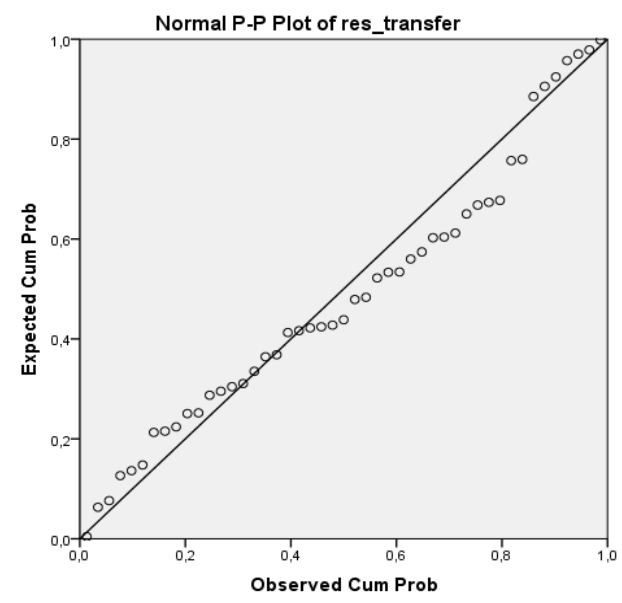

GAMBAR 7. P-P Plot residual

\section{Peramalan}

Tahap terakhir yang dilakukan adalah melakukan peramalan menggunakan model fungsi transfer yang terpilih. 


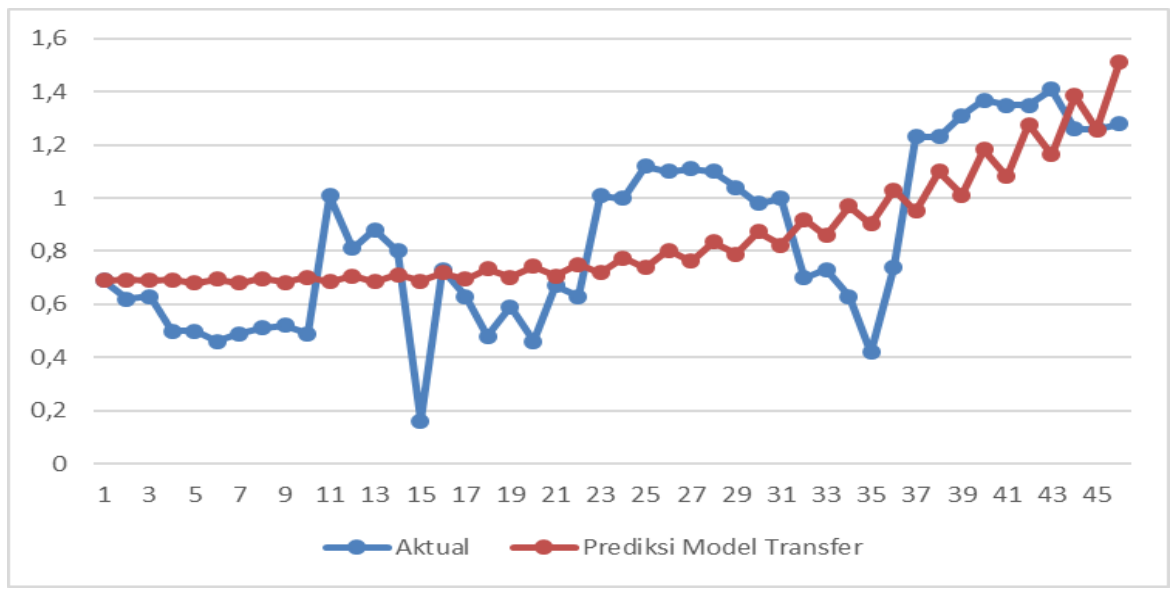

GAMBAR 8. Plot nilai aktual ROA dan nilai prediksi menggunakan model fungsi transfer

Pada plot Gambar 8, terlihat garis yang menggambarkan prediksi model fungsi transfer single input searah dengan nilai ROA aktual. Penghitungan MAPE untuk model peramalan adalah sebesar 32,46\%, yang mengindikasikan bahwa model fungsi transfer single input termasuk kategori cukup baik dalam memprediksi ROA. Hal ini disebabkan hanya digunakan satu variabel yaitu tingkat suku bunga tabungan bank konvensional untuk memprediksi ROA bank syariah.

\section{KESIMPULAN DAN SARAN}

\section{Kesimpulan}

Pemodelan fungsi transfer single input untuk meramalkan ROA bank syariah berdasarkan variabel input suku bunga tabungan bank umum konvensional menunjukkan bahwa suku bunga tabungan bank umum konvensional berpengaruh secara signifikan terhadap ROA pada lag ke-3. Hasil diagnostik residual menunjukkan bahwa model fungsi transfer single input telah memenuhi asumsi normalitas dan white noise. Nilai MAPE sebesar 32,46\% mengindikasikan bahwa model peramalan cukup baik dalam memprediksi ROA.

\section{Saran}

1. Hasil peramalan dapat digunakan sebagai dasar kebijakan untuk menentukan strategi dalam pengembangan industri perbankan syariah.

2. Pada penelitian selanjutnya, dapat ditambahkan variabel lain untuk memprediksi ROA bank syariah agar hasil peramalan yang diperoleh lebih akurat.

\section{UCAPAN TERIMA KASIH}

Terima kasih kepada Bapak Dr. Toni Toharudin, M.Sc atas bimbingannya untuk penelitian ini.

\section{REFERENSI}

Aryasita, \& Mukarromah. (2013). Analisis Fungsi Transfer pada Harga Cabai Merah yang Dipengaruhi oleh Curah Hujan Di Surabaya. Jurnal Sains dan Seni Pomits vol.2, No.2, (2013) 2337-3520 (2301-928X Print).

Makridakis, S. (1999). Metode dan Aplikasi Peramalan (2nd ed.). Jakarta: Binarupa Aksara.

Syah, T. Aldian (2018). Pengaruh Inflasi, BI Rate, NPF, dan BOPO terhadap Profitabilitas Bank Umum Syariah di Indonesia. Jurnal Ekonomi Islam Vol.6 No.1 Januari-Juni 2018. 
Tsay, R. S. (2013). Multivariate Time Series Analysis: With R and Financial Applications. John Wiley \& Sons.

Wahyuningsih, Sri. (2012). Pemodelan Nilai Tukar Petani Padi Palawija dengan Pendekatan Fungsi Transfer dan Multivariate Adaptive Regression Spline Time Series. Tesis. Surabaya: Institut Teknologi Sepuluh November (ITS).

Wei, W.W.S. (2006). Time Series Analysis Univariat and Multivariate Methods Second Edition. Canada: Addison-Wesley Publishing Co. 